\title{
Examining Municipal Councillors' Oversight Roles in Alfred Nzo District Municipality of the Eastern Cape, South Africa
}

OKAFOR, Chukwuemeka |MATIWANE, Solomon | ONUIGBO, Richard Amechi

\section{Abstract}

$\mathrm{T}$ his study reviews the oversight roles played by municipal councillors in Alfred Nzo District Municipality, Eastern Cape Province, South Africa. The objective is to determine the appropriate strategies that can be recommended for improving effectiveness of leadership, i.e., council structures. This is against the backdrop of the Auditor-General's audit report for three financial years (2008-2011), which revealed the weakness of the systems of the municipal councils, including internal controls and inadequate leadership. These audit findings had been highlighted as the basis for irregular, fruitless and wasteful expenditures that results to a series of adverse and disclaimer audit reports. Using a qualitative methodology approach with a descriptive design, the study attempts to assess the extent to which the political leadership of the municipality performs its roles in response to expectations of good governance and service delivery. The findings show apparent shortcomings in the administrative procedures. To achieve improvement in good governance, financial accountability and service delivery, the study recommends for improvement in educational and leadership capacity of elected councillors.

Keywords: Oversight, Good Governance, Accountability, Transparency, Service Delivery, Alfred Nzo, Eastern Cape, South Africa. 
Examining Municipal Councillors' Oversight Roles in Alfred Nzo District Municipality 53

\section{Introduction}

The Alfred Nzo District Municipality, like other municipalities in the country, derives its existence from the Constitution of the Republic of South Africa, 1996. The South African Constitution provides for a national system of local government. It charges local governments with a developmental mandate and equips each municipality with a set of constitutionally protected powers. The provincial government is tasked with supervising and supporting roles over municipalities, but plays a minor role with regards to regulating local government. The Alfred Nzo District Municipal Council comprises councillors who are democratically elected according to the electoral system that combines constituency (60\% local representatives) with proportional representation (40\% party system).

The municipal council's legislative mandate includes, but not limited to: authority to enact legislation at local level, also known as by-laws or regulations, in certain areas such as Integrated Development Plan (IDP), Budget and Service Delivery Implementation Plans (SDBIP) and also ensuring that good governance is achieved (Municipal Finance Management Act, 2003). Councillors, therefore, have a mounting pressure to be responsive to the demands of internal and external stakeholders for good governance, accountability and transparency and delivery of tangible services to the citizens. They are expected to communicate the policies and decisions to their local residents. According to Ijeoma, et al (2013:95) this promotes trust between the municipality and the local community and also educates citizens with regard to the issues which councillors are dealing with. As such, when community members obtain insights into the operations and policies of the municipality they are likely to develop into better citizens.

The case study at Alfred Nzo District Municipality is basically about an assessment of effectiveness of oversight roles played by municipal councillors over the administration. The municipality had continuously received adverse and disclaimer audit from the Auditor-General of South Africa for three consecutive financial years. The study, therefore, examines the cause of poor performance of the municipality and the effect of oversight roles played by councillors as regards service delivery in the municipality. The Alfred Nzo District Municipality is one of the six district municipalities in the Eastern Cape Province. The municipality has a total population of approximately 801344 and the geographical area is $11119 \mathrm{~km} 2$ (Alfred Nzo Municipality, 2010). 


\section{Problem Statement}

The Alfred Nzo District Municipality (ANDM) is a public institution led by a democratically elected municipal council. The municipality has made tremendous contributions to the impressive record of extending services to the remote and marginalized communities in the area. However, the challenges facing the municipality remain daunting. The municipality is confronted with a serious challenge in view of the negative public perception about corruption in the country. The other concern borders on achieving clean audit and effective leadership with sound internal controls. Nonetheless, government structures in Alfred Nzo District Municipality are operational; including political structures that are given a responsibility to play political oversight roles over the administration. The quality and effectiveness of oversight structures is sometimes questionable due to the number of fiscal years wherein the municipality has continued to receive adverse or disclaimer audit opinions from the Auditor-General of the country.

This study explores the extent to which the best practices of oversight can impact on service delivery and in achieving the set goals as enclosed in the Integrated Development Plan (IDP) of the municipality. It further examines the role played by councillors (municipal leadership) over administration. The study, therefore, proposes practices and/or mechanism of oversight within the institution. The main aim is to ascertain the shortcomings and make recommendations that will be presented to the leadership of the council.

\section{Policy Context of the Study}

According to the Constitution of the Republic of South Africa (Act 108 of 1996), section 151(2) stipulates that both executive and legislative powers rest within the municipal council. This results into difficulty to clearly define the separation of powers within the council. The Municipal Structures Act, 1998 (Act 117 of 1998) establishes committees of council in terms of sections $79 \& 80$ thereof, for effective and efficient performance of any council's functions or the exercise of any of its powers. It is also imperative to have some understanding of the accountability framework for municipalities in order to correctly understand the role of the oversight roles played by councillors. As previously indicated in local government, there is no clear line of separation of powers. The legislative and executive authority is seated in the Municipal Council, of which councillors 
as the members are elected representatives of political parties. For example, an item on the construction of regional water scheme is tabled to Council. Here, councillors are obliged to vote according to the party caucus decisions. King (2009:5) notes that the Executive Mayor, as well as the municipal councillors are elected to represent a political party. King (2005) further argues that the principle of independence to Mayors does not apply as they are guided and assessed in terms of party manifestos instead of being based on sound business principles.

Practically, the Alfred Nzo District Municipality operates under the leadership of an Executive Mayor, a councillor elected by the Council. On the other hand, the Council meetings are chaired by the Speaker of Council. Indirectly, the Executive Mayor accounts to the Speaker as he/she is obliged to report to the Council (a body that holds the Executive Mayor accountable for the execution of the Council decisions). Section 160 of the Constitution, 1996 on Internal Procedures prescribes that municipal council may make by-laws about rules and order to regulate internal arrangements, business proceedings and its committees. Therefore, the roles and responsibilities of Council should always be carried with a clear distinction between oversight and interference in administration as defined in the Municipal Finance Management Act (MFMA) sections 52 (b) and 103 respectively, as well as in the Code of Conduct for Councillors, which is defined in Schedule 1 of the Municipal Systems Act, No. 32 of 2000. The Municipal Finance Management Act (MFMA) Circular 32 of 15 March 2006 provides guidance on the oversight process that the council must follow when considering the Annual Report and producing an Oversight Report.

The reformed programme, including the development of new Annual Reports, has progressed over the past few years and certain challenges experienced in the municipality are now being addressed by the existence of Municipal Public Accounts Committee (MPAC), a committee formed in terms of section 79 of the Municipal Structures Act.

The Municipal Public Accounts Committee (MPAC) is a new model of oversight function played by Council over the executive and it provides an appropriate mechanism in which the Council could fulfil its oversight responsibilities. It helps the Council to deal with challenges relating to the need of continuous improvement in service delivery and promotion of accountability and transparent governance arrangements. This also helps to increase Council and public awareness on the financial and performance related 
matters of the Municipality and its entities, including policy operation and implementation of local government legislations. King (2010:7) asserts that the establishment of Municipal Public Accounts Committees (similar to the Standing Committee on Public Accounts (SCOPA) in Parliament) will complement the functions of the Municipal Audit Committees. King (2010) however, cautions that municipalities should further apply the principle of good governance, which dictates that audit committees should satisfy itself of the expertise, resources and experience of the municipality's finance function.

The Audit Committee is an independent advisory body that advises Council, political office-bearers, the accounting officer, and the management of the municipality, including the management staff of the municipality entity on matters related to internal control, internal audits, risk management accounting policies and adequacy reliability and accuracy of financial reporting and information, performance compliance with the MFMA and the Division of Revenue Act. The Municipal Public Accounts Committee (MPAC) undertakes and manages similar functions and responsibilities for the Municipality, as undertaken by SCOPA in the national and provincial legislatures, except for certain powers regarding subpoena of individuals. In the case of any irregular expenditure or any fruitless and wasteful expenditure incurred by the municipality or municipal entity, the MPAC has the right to call the Accounting Officer of the municipality or the chairperson of the municipal entity's board of directors to appear before it and provide information or clarity. The MPAC is allowed to engage directly with the public and consider public comments and is entitled to request for documents or evidence from the Accounting Officer of the municipality or municipal entity.

The study's findings show that there are limitations and challenges impeding the successful realization of effective oversight role played by councillors in service delivery with the aim to achieving the ultimate goal of good governance at Alfred Nzo District Municipality. The policy relevance of the study therefore, hinges on identifying these challenges and limitations and their impacts on effective performance, good governance and efficient service delivery. 


\section{Study Coverage, Methodology and Analysis}

The study methodology is case-study design with a focus on qualitative analysis. Qualitative research methodology was selected due to the fact that the methodology is descriptive and stresses the importance of context, setting and participants' frames of reference. According to Okecha (2011:17), qualitative researchers rely on four techniques for gathering information, namely: (1) analyzing documents and material culture, (2) observing directly, (3) participating in the setting, and (4) interviewing in-depth. All four techniques were utilized in this research. The techniques used to collect data in the study are briefly explained in the following manner:

- The literature review was used to study policy documents and other textual data.

- Questionnaires were administered to three different groups comprising councillors, top municipal administrators and party stakeholders. Each group comprised 20 participants.

- Structured interviews, using pre-designed questions were administered to a select group of municipal workers, and community leaders/representatives. The structured questions were presented in three streams of 20 participants each. The advantage of the interview was that it presented an opportunity of participants with limited low literacy level to answer the open-ended questions and this enabled the researchers to collect in-depth data regarding people's assessment.

- The interactive interviews afforded the researchers an opportunity to gather an observational data by collecting direct data from participants (councillors). This observation of participants' reactions to understand the council better and uncover things that the participants might have not freely talked about when completing the structured questionnaire. The researchers participated in three clusters of discussions involving elected councillors, stakeholders and municipal administrators.

\section{Findings}

In terms of the determinants of effective leadership for oversight and accountability, the study findings show that local government is at the centre stage grass roots of service delivery (Voice of Local Government, Issue-12 October 2014). It is therefore, imperative 
to note that municipalities are at the forefront of improving the lives of the communities they serve. They have to create conditions for inclusive economic and job creation. This requires an effective calibre of leadership (councillors) that can put service delivery high on the local government agenda. Van Zyl et al (2009:6) argue that "one useful way to gain understanding of leadership in the business organization is to examine various roles carried out by leaders." The role in this context is an expected behaviour or activity stemming from one's job or position. Essentially, the understanding of the roles, responsibilities and expectations of councillors in local government is very important in order to achieve their effective oversight roles and accountability. The understanding of these roles and responsibilities by councillors would enable them to comprehend on what is expected of them by the communities they serve. Nevertheless, it is critical to understand that section 151(2) of the Constitution, 1996, vested both legislative and executive authority in a Municipal Council.

In summary, the study findings show the following limitations:

- lack of delegation framework and strategic roles for political office-bearers and other designated councillors;

- limited public participation with identified capacity gaps in the three strategic offices of the Mayor, Speaker and Council Whip;

- limited compliance with legislation and lack of credibility of the Integrated Development Plan (IDP);

- lack of monitoring, evaluation and reporting systems - something that makes the portfolio committees and/or governance structures not to be able to detect early warnings of maladministration and corruption.

- ineffective intergovernmental relations (IGR) structures; this resulted to poor information sharing, poor performance management and lack of customer care services.

The second issue borders on the role of the political office-bearers for oversight and accountability as a measure for transparency and accountability to the stakeholders. The findings as shown in figure 1 reveal that 16 of the 20 interviewed participants indicate that, to some extent, the strategic roles of the three critical seats of political power in the municipality (Executive Mayor, Speaker and Council Whip) that constitute the so- 
called political management or TROIKA of the municipality are not clearly defined. In this instance, it was indicated that there is no clear delegation to any of the above political offices as to who is responsible for public accountability on the performance of the municipality. The problem refers to stakeholder relations.

Figure 1: Response on the role of political office-bearers for oversight and accountability as a measure for transparency and accountability

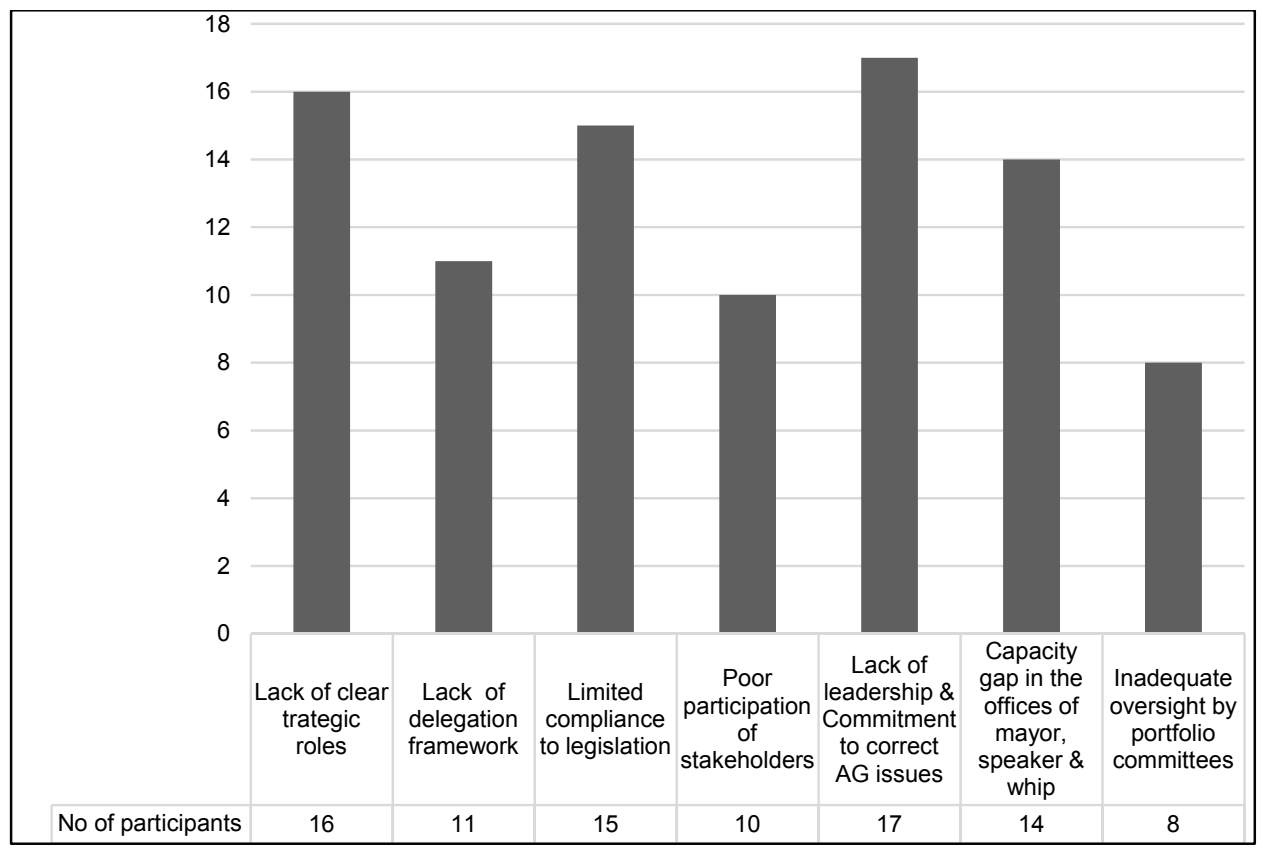

Section 30 of the Municipal Systems Act, No. 32 of 2000, states that "the Executive Mayor must, in accordance with section 29 of the Act, manage the drafting of the municipality's Integrated Development Plan." The Executive Mayor is also required to submit the draft IDP, which has taken into account the public comments to the municipal council for adoption. Section 121 (3)(a-k) requires that the Executive Mayor must ensure that the Annual Report, which contains the information on predetermined objectives and the record of the activities of the municipality during the financial year to which the report relates, complies with the requirements of the Act. According to section 49 of the Municipal Structures Act, No. 117 of 1998, the Mayor is required to manage 
and preside over the meetings of the executive committee. In this regard, the Mayor is also expected to perform ceremonial functions as the public figure. In terms of section 49(b) of the Act, the Mayor is expected to exercise the delegated powers assigned to him/her by the municipal council or the executive committee.

The Executive Mayor remains the most politically visible office-bearer with the responsibility to represent the municipality politically, and also to communities. Therefore, it is appropriate to locate the function of community liaison and public participation (community consultation outreach) required for the approval of IDP and annual budget to the Executive Mayor. This correctly positions the Executive Mayor to be responsible for prioritizing community needs and/or defending municipality's policy positions. On the other hand, section 160(1) (b) calls for a Municipal Council to elect its chairperson, but the Constitution does not stipulate specific roles and responsibilities of that chairperson. The White Paper on Local Government is silent on the issues of the speaker. Section 36 of the Municipal Structures Act interprets section 160(1) (b) of the Constitution by naming the chairperson to be elected by the municipal council as the Speaker.

The Speaker is the custodian of council decisions, this role emanates from the position he/she is occupying. Section 37 of the Municipal Structures Act states the regulated functions of the Speaker of a municipal council as to: (a) preside at meetings of the municipal council, and (b) perform the duties and exercise the powers delegated to the speaker in terms of section 59 of the Municipal Systems Act.

Steytler and De Visser (2004) view that the introduction of the office of Speaker was informed by the wish to establish a framework for municipalities to entrench mechanisms for ensuring oversight, accountability, integrity, discipline of office, and the efficient running of council meetings. The effective system of delegation and clear terms of reference for each political office realizes the idea of separation of functions to ensure effective oversight and accountability in pursuit of good governance. With regard to the Council Whip, the office of the Chief Whip plays less role in providing strategic leadership for the municipality to address AG queries, whereas it plays a central role in terms of ensuring that councillors as public representatives are timeously reporting to their constituencies about the developmental programmes undertaken by the municipality. The office of the Chief Whip functions in terms of delegation framework and remains the centre within the council that coordinates political programmes; this 
includes continuous assessment on the implementation and fulfilment of the manifesto for the ruling party.

In assessing the role of Councillors in the achievement of predetermined objectives as set out in the Integrated Development Plan, the IDP is found to be a strategic plan of the municipal development. The IDP process is designed to be participatory in nature in order to determine the municipal priorities for development. It contains the most important features of 'developmental local government' such as Local Economic Development (LED). Ijeoma, et al (2013: 256) opines that IDP is the central instrument of local government in South Africa and functions as a principal planning instrument, which serves as a bedrock for local government budgets, financial plans, performance management and service delivery processes. It was noted that councillors have to adopt a plan for developing the municipality during their term of office. Linked to the IDP is the budget that projects costs for the plans set out in the IDP. It was also noted that councillors have also to check that the IDP fits the development plans of other institutions (growth plans of state departments and IDPs of local municipalities) in the area. Figure 2 shows the role of councillors in the achievement of predetermined objectives of the council.

Figure 2: The role of councillors in the achievement of predetermined objectives

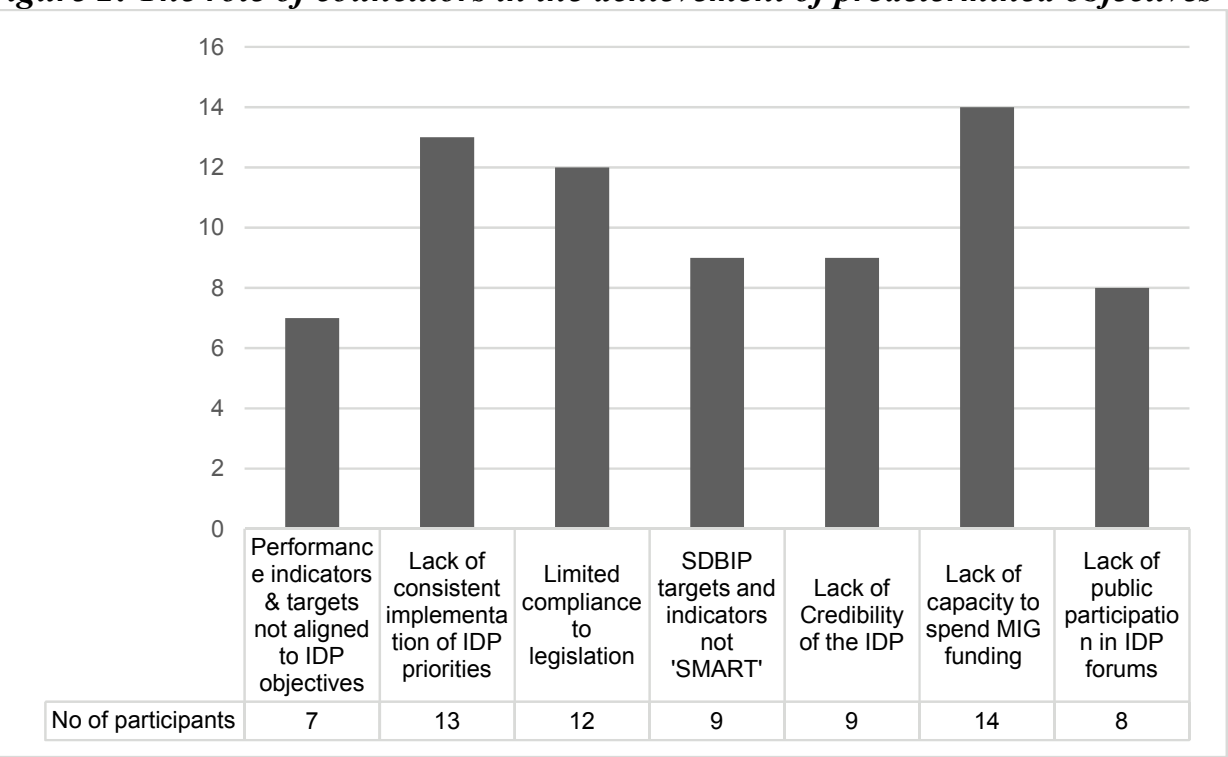


It was observed that councillors are required to conduct public road-shows and report on the progress of implementing IDP and budgets plan. In this process, they have to account for the actual results achieved against the planned targets. In the consultative process, highlights should be provided in the following areas, but not limited to the:

- amendments made to the IDP and proposed changes to the budget related policies such as tariff charges, credit control and indigent policies,

- political priorities and linkages of the IDP to the National Development Plan (NDP) and Provincial Growth and Development Plan (PGDP),

- the past and current performance of the municipality by indicating achievements, major priorities for the past and current periods, and

- outlined service delivery standards, expected outcomes with time lines for achievement and financial implications.

In figure 2, 14 out of the 20 interviewed participants indicated lack of political leadership and oversight over the MIG expenditure that is supposed to be provided by councillors. Participants argue that once the IDP and budget are approved by the Council; the Executive Mayor is expected to discharge his/her responsibility by receiving and signing the 'service delivery and budget implementation plan (SDBIP), which has been generated by the accounting Officer. The aim is to ensure that there is a strong and clear plan for financial and non-financial governance and/or accountability. By definition, the SDBIP is an implementation and management tool for municipal IDP and budget within a given financial year. The Executive Mayor approves the SDBIP together with the annual performance agreements of the Municipal Manager and senior managers. The interviewed participants in this case contended that councillors seem to be relaxed and leave the implementation process to the mercies of salaried officials once the IDP, budget and SDBIP are approved. It was noted that the Supply Chain Management (SCM) processes for the Alfred Nzo District Municipality were almost lacking political oversight.

The local government legislation has made provisions for continuous monitoring and evaluation of the implementation of the predetermined IDP objectives. Section $37(\mathrm{~d})$ of the Municipal Structures Act, No. 117 of 1998, in defining the functions of the speaker, warrants that "the speaker of a municipal council must ensure that the council meets at 
least quarterly." This mandatory obligation is concealed by sections 71 and 72 of the Municipal Finance Management Act, No. 56 of 2003. The main objective of the Act is to cause the council to assess the performance of the municipality and municipal entity on quarterly and mid-year basis. What caused concern to the interviewed participants was the fact that, in all these statutory intervals of reporting, councillors are unlikely to detect the improper practices of maladministration and corruption.

Another issue of concern borders on enhancing coordinated oversight for transparency and better financial accountability. The main aim of the Local Government Turn-Around Strategy (LGTS) was to build clean, effective, efficient, responsive and accountable local government. The concept of 'oversight' refers primarily to the critical role played by authorities (National Assembly and Provincial Legislatures) in reviewing and monitoring the actions of the executive organs of government. Section 55(2) of the Constitution, 1996, requires the National Assembly to provide for mechanisms to ensure that all executive organs of state in the national sphere of government are accountable to it. Sections 55(2) and $114(2)$ of the Constitution, 1996, respectively, require the National or Provincial Legislatures to provide for mechanisms to ensure that the national or provincial executive organs of state in the national or provincial sphere/s of government are accountable to it. In the context of local government, there is no clear distinction between the executive and legislative functions. To a greater extent, in the municipality, the executive and legislative functions are jointly performed by the Council. Figure 3, shows the degree of achieving coordinated oversight for transparency and better accountability in governance.

In figure 3, 17 out of the 20 interviewed participants pointed out that the municipality lacks effective monitoring and evaluation systems. They argued that the function of oversight by councillors is supposed to be an all year process. This requires the key role-players (councillors) to be diligent and consistent in executing their responsibilities. For example 17 of the 20 participants stated that the lack of risk governance, non-functionality of audit committee, lack of capacity to internal audit and risk units poses challenge for the municipality to be unable to detect signals of fraud and corruption. 
Figure 3: Enhancing coordinated oversight for transparency and better accountability

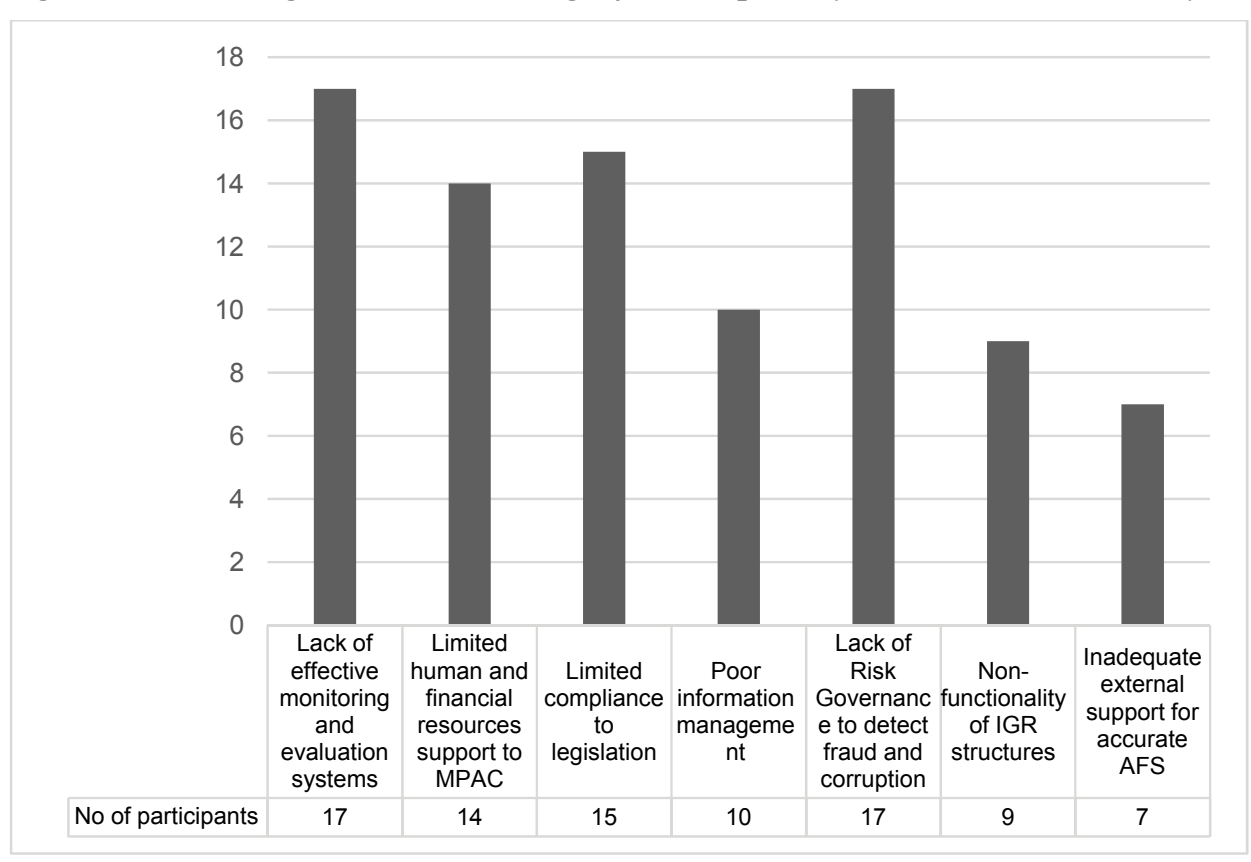

There is also the issue of good governance through understanding the role of councillors in service delivery and municipal performance. In this case, effective oversight is noted as mainly being about consistent maintenance of good governance. This assists to ensure that business ethics and values are maintained. Again, the critical point here is the culture of an organization to comply with the legislation governing local government for clean administration and delivery of services with honest and impartiality. Bovaird and Loffler (2009:217) write that good governance has eight major characteristics, namely: participatory, consensus-orientated, accountable, transparent, responsive effective, efficient, equitable and inclusive and follows the rule of law.

In figure 4, 18 out of the 20 interviewed participants claimed that poor performance management declines the performance status of the municipality whilst, on the other hand, the councillors of the municipality have good dreams to improve the lives of the community they serve.

The cited example was the decision taken by the council to purchase and maintain the fleet of plant machinery with the aim to fast-track the provision of services like 
construction of access roads and thus boosting the capacity of local municipalities that are sitting at huge infrastructure backlog.

Figure 4: Good Governance through understanding the role of councillors in service delivery and municipal performance

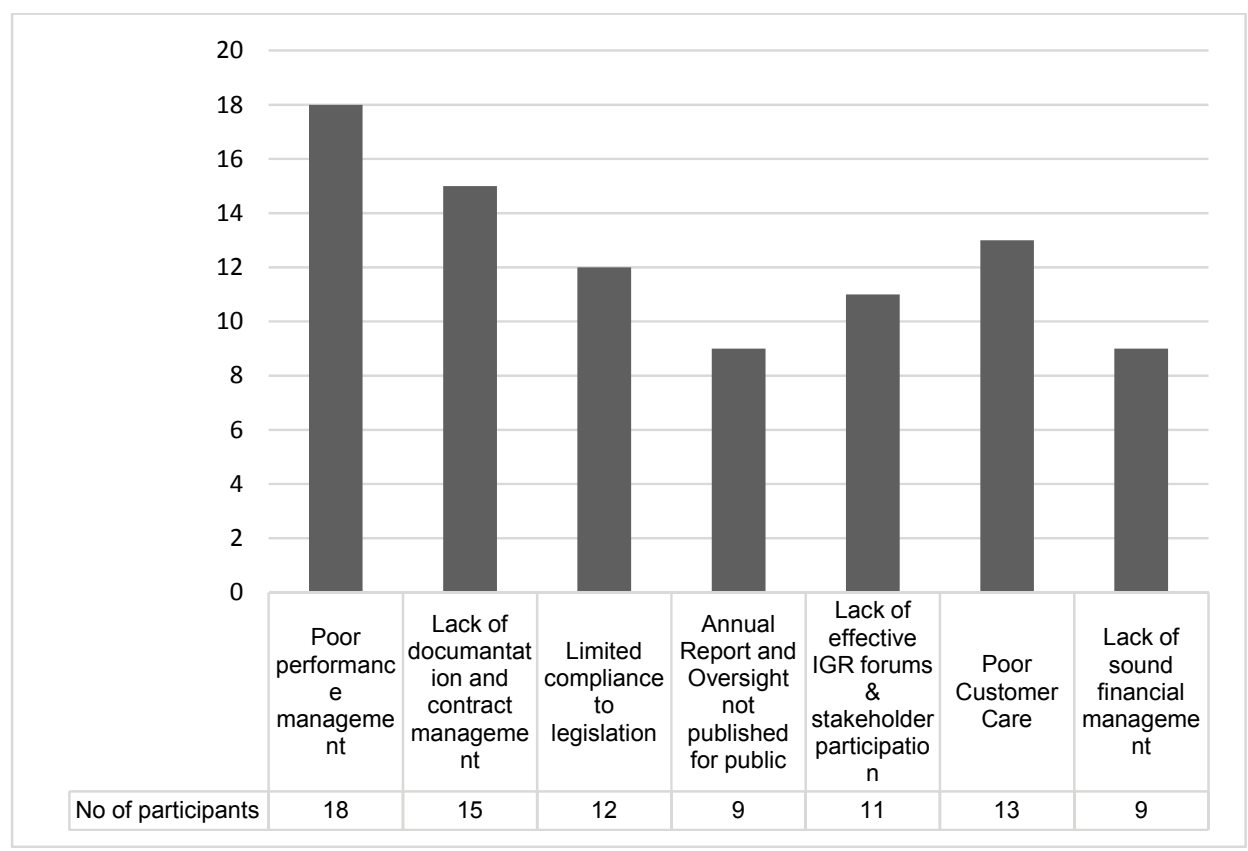

Then, 12 of the 20 participants pointed out that although the idea was good, lack of performance management made the idea unsuccessful. The critic was that there were no performance contracts in place for senior managers at that time under study, as results there was complete poor asset management with no consequential measures in place. It was noted that the question of poor asset management, especially fleet management led to the Alfred Nzo District Municipality to unilaterally cease to operate the plant machinery.

Figure 5 shows that 15 of 20 interviewed participants indicated good record management is the major determinant on the effect of internal controls that are used to improve the performance of the municipality. 


\section{Figure 5: The effect of Internal Controls}

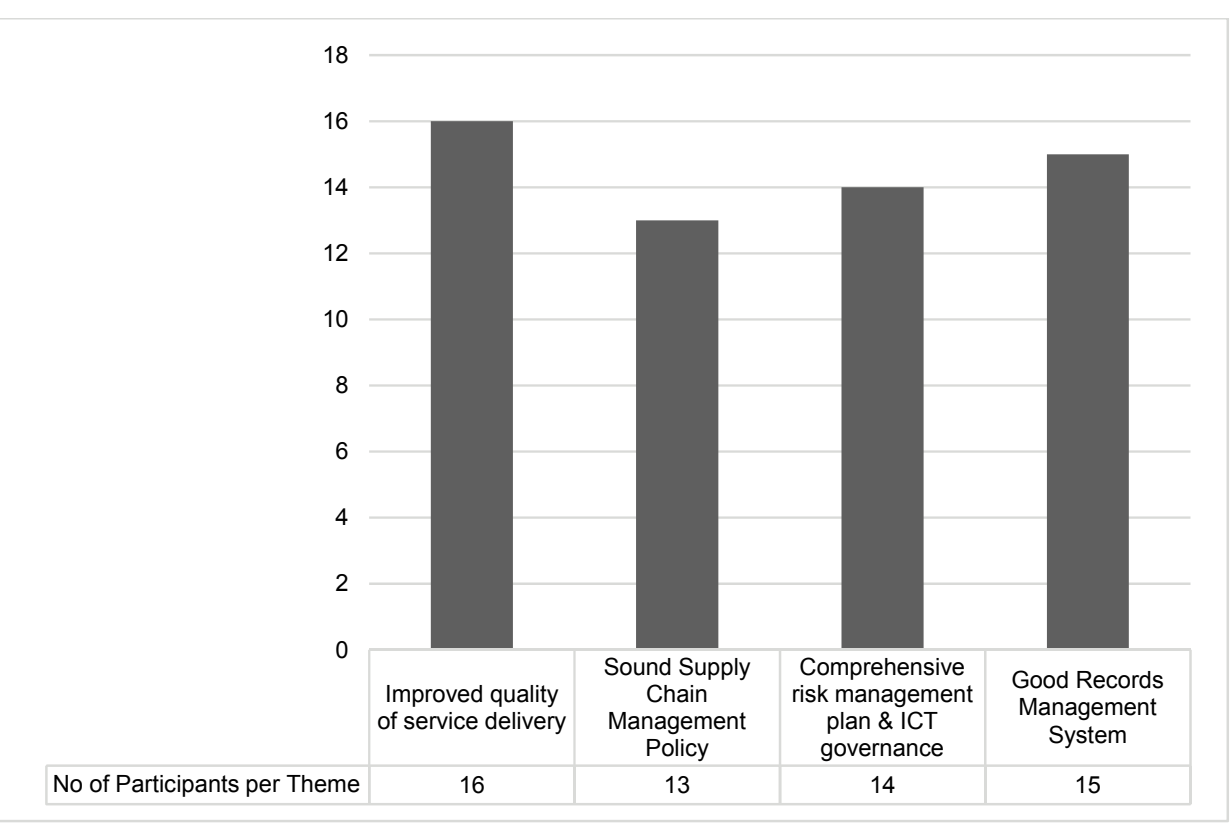

The internal controls are essential measures designed for the effective operation of the public or private institution. Simply put, the internal controls are basically the activities or procedures designed to provide reasonable assurance that the operations of the institution are going according to plan. Internal controls are management tools and without the adequate internal controls, the management has less assurance that the organizational goals and objectives will be achieved. Here, properly designed and functioning controls reduce the possibility that significant risk, errors or fraud will occur and/or remain undetected. The internal controls also assist to ensure that departments like Budget and Treasury Office (BTO) are performing as expected. These include: sound supply chain management policy, internal audit, and comprehensive risk plan, governance of Information Communication and Technology (ICT) and good record management system.

\section{Suggestions for Enhanced Performance}

It is imperative that Alfred Nzo District Municipality considers and applies the following measures in order reach its vision and objectives and ultimately achieve good 
governance through effective and efficient oversight played by councillors. The study therefore recommends the following:

- that the capacity of councillors with lower educational qualifications should be improved. This should be done to avoid the limited capacity of councillors to interrogate reports developed and presented by officials. It must be noted that the limited capacity of councillors to engage officials undermines their capacity to monitor the progress of projects implemented.

- that the municipality should adopt the model of separation of functions and at the same time the office of the speaker should be delegated to prioritize and monitor the capacity building programmes for councillors and account by reporting to the municipal council.

- that in order to mitigate the potential of tensions, if the roles of the council chief are not clearly delineated, the Council Whip should be responsible for receiving and approving the application of leave of absence to both the municipal council and its committees. Additionally, the Council Whip should be delegated in writing to assign members to portfolio committees and assist the speaker in the application of the Code of Conduct for Councillors. The rationale is that the Council Whip has a direct mandate to represent the ruling party's interests in terms of implementing the political party's manifesto and other political in the council.

- to make effective use of the oversight structures like Audit Committee and Municipal Public Accounts Committee. These committees can offer the prospect of enhancing oversight and accountability for credibility, trust and reputation amongst the municipal stakeholders.

- that the municipality should make efforts in turning around and professionalizing the municipal administration to ensure that it has positive spin-offs and enhanced its constitutional objectives of effective, efficient and economic service delivery to the communities it serves.

- that the municipality implements the PMS from top management to the lower levels of the organogram. The political leadership should do due diligent and compensate or incentivized those deserving, thus to mitigate despondencies 
and disgruntlement amongst those being assessed and achieved or outperformed in achieving their targets and performance indicators. Moreover the municipality must maintain a logical sequence of IDP processes informed by the realistic budget that should be developed, and be a true reflection of the needs of the communities.

- that the municipality must develop and maintain sound financial and ICT management systems for proper filing to ensure that records of financial affairs are properly kept. Besides, the municipality must develop and maintain adequate internal controls by following laws or procedures and approved supply chain management (SCM) policy when awarding tenders.

\section{Conclusion}

Given the above scenario, it is concluded that the councillors should harness the expertise of management by creating conducive environment for good working relations and order. This will guarantee job security, professionalism and confidence amongst managers and make them to exercise their authority, discharge executive responsibilities and account freely for their actions without being undue pressure and influence on matters of administration. This is mainly subscribed to the external environment of political instability and factionalism with the party in power at the time.

The councillors interviewed reflected on a number of achievements of the municipality. These achievements were attributed to the effective performance of councillors' roles and functions despite the challenges faced by the municipality. It was reported that a tremendous work has been done by the current political leadership to turn the situation around. This includes the filling of all critical posts of senior managers, including the signing of employment and performance contracts by senior managers. As a result, the Alfred Nzo District Municipality has achieved an unqualified audit opinion for 2013-2014 financial year.

Furthermore, it was reported that the Alfred Nzo District Municipality defied all odds and achieved the "Blue Drop" status of $64 \%$ being number four in the province the almost impossible, given the municipality's background on infrastructure backlog that has been made worst by dilapidated water infrastructure. If the study recommendations 
are adopted, improved performance, good governance and service delivery efficiency will be achieved.

\section{List of References}

- Bovaird, T. \& Loffler, E. 2009. Public Management and Governance. $2^{\text {nd }}$ edition. Routledge. London.

- Carrim, N. 2011. Domestic Participation, Decentralization and Educational Reform: Implementing Education Policies: The South African Experience. Cape Town: University of Cape Town Press.

- Cohen, L., Manion, L., and Morrison, K. 2000. Research Methods in Education. $5^{\text {th }}$ Edition, RoutledgeFalmer. London.

- Cooper, D.R. \& Schndler, P.S. 2005. Business Research Methods. McGraw-Hill Education. UK.

- Clifford, N., \& Valentine, G. 2003. Key Methods in Geography. UK. Sage Publishers.

- Flowerdew, R., \& Martin, D. 2005. Methods in Human Geography, 2nd Edition. UK. Pearson.

- Hornby, A.S. 2010. Oxford-Advanced Learner's Dictionary of Current English, 6 ${ }^{\text {th }}$ Edition, Oxford University Press, New York.

- Ijeoma, E. et al. 2013. South Africa's Public Administration for Community Service. ISDMN. South Africa. University of Fort Hare.

- Irvin N. Gleim, 2011. CIA Review. Part III, Business Analysis and Information Technology. Gainesville, Florida: University Station

- Kirilo, S. 2005. Policy and Governance: Australia's Governance Aid-Evaluating Evolving Norms and Objectives; Discussion Paper, the Australian National University.

- Kvale, S. 1996. Interviews. London: Sage Publishers.

- Lofland, J., Snow, D., Anderson, L. and Lofland, H. 2006. Analyzing Social Settings. A guide to quantitative observation and analysis. $4^{\text {th }}$ edition. Belmont. Wadsworth.

- McGrath, R.J. 2011. Public Administration Theory and Practice: General Principles of Delegation. University of Iowa. 
- Neuman. G. 2005. Social Research Methods: Qualitative and Quantitative Approaches. Wageningen University.

- Okecha, K. 2001. Regime Politics and Service delivery: Cape Town Unicity Council Area. Lambert Academic Publishing. Cape Town.

- Phillip, L.J. 1998. Combining Quantitative and Qualitative Approaches to social research in human geography.

- Republic of South Africa. 1996. The Constitution of the Republic of South Africa, Act 108 of 996. South Africa. Pretoria.

- Republic of South Africa. 1998. The Local Government: Municipal Structures Act 117 of 1998. Department of Provincial and Local Government. South Africa. Pretoria

- Republic of South Africa. 1998. The White on Local Government- Department of Provincial and Local Government. South Africa. Pretoria.

- Republic of South Africa. 1998. The Local Government: Municipal Systems Act 32 of 2000. Department of Provincial and Local Government. South Africa. Pretoria.

- Republic of South Africa. 1998. The Local Government: Municipal Structures Act 117 of 1998. Department of Provincial and Local Government. South Africa. Pretoria.

- Republic of South Africa. 2003. The Local Government: Municipal Finance Management Act 56 of 2003. Department of Provincial and Local Government. South Africa. Pretoria

- Republic of South Africa. 2004. Public Audit Act 25 of 2004. South Africa. Pretoria.

- Republic of South Africa. 2010. King III Code of Governance for South Africa 2010. South Africa. Pretoria.

- Republic of South Africa. Municipal Integrated Development Planning. (Issued by GPLG). South Africa. Pretoria.

- $\quad$ Republic of South Africa. 2014. SALGA Bulletin, $1^{\text {st }}$ Edition 2014. South Africa. Cape Town.

- Republic of South Africa. 2009. The Local Government Turnaround Strategy; Moving together, Turning the tide in Local Government. Department of Cooperative Governance and Traditional Affairs. South Africa. Pretoria.

- Republic of South Africa. 2005. Intergovernmental Relations Framework Act 13 of 2005. South Africa. Pretoria

- Republic of South Africa. 2001. Public Service Regulations, 2001. South Africa. Pretoria. 
Examining Municipal Councillors' Oversight Roles in Alfred Nzo District Municipality 71

- Republic of South Africa. 2014. Local Government Regulations, Gazette No. 37245, 2014. South Africa. Pretoria.

- Republic of South Africa.2014. SALGA Bulletin, $1^{\text {st }}$ Edition 2014. South Africa. Cape Town.

- Republic of South Africa. 2013. SALGA Discussion Paper; with Corruption everyone pays. South Africa. Cape Town.

- Republic of South Africa. 2010. Special Investigation Report-ANDM. Local Government:

- Department of Cooperative Governance and Traditional Affairs. South Africa. Pretoria

- Republic of South Africa. 2014. SALGA Bulletin, $1^{\text {st }}$ Edition 2014. South Africa. Cape Town.

- Republic of South Africa. 2014. SALGA VOICE of Local Government, Issue 12 Edition 2014. South Africa. Cape Town.

- Republic of South Africa. 2013. SALGA Discussion Paper; with Corruption everyone pays. South Africa. Cape Town.

- Steytler, N. \& De Visser, J. 2004. Enhancing Accountability and Integrity of, and oversight in municipalities: Local Government Bulletin, South Africa. Cape Town.

- Smit, B. 2003. Introduction to Qualitative Research: Education Management Law and Policy. University of Pretoria. Pretoria.

- Strauss, S \& Corbin, R.G. 2003.Basic Qualitative Research Techniques and Procedures for Developing Grounded Theory. Thousand Oaks.

- Van Zyl, E., Dalglish, C., Duplessis, M., Lues, L. \&Pietersen, E. 2009. Leadership in the African Context. Juta \& Co LTD. Cape Town, South Africa.

- Welman, Kruger \& Mitchell.2007. Research Methodology, Cape Town: Oxford University press.

\section{AUTHORS' CONTACT:}

\begin{tabular}{|c|c|c|}
\hline $\begin{array}{r}\text { OKAFOR, Chukwuemeka } \\
\text { Dept of Political Science } \\
\text { Enugu State University of Science } \\
\text { and Technology } \\
\text { Email: } \\
\text { emeka.okafor250@gmail.com }\end{array}$ & $\begin{array}{l}\text { MATIWANE, Solomon } \\
\text { Dept of Community Service } \\
\text { Alfred Nzo District } \\
\text { Municipality } \\
\text { Eastern Cape } \\
\text { Email: } \\
\text { matiwanesolomon@gmail.com }\end{array}$ & $\begin{array}{l}\text { ONUIGB0, Richard Amechi } \\
\text { Dept of Political Science } \\
\text { Enugu State University of } \\
\text { Science and Technology } \\
\text { Email: } \\
\text { ifeifeonuigbo@yahoo.com }\end{array}$ \\
\hline
\end{tabular}

